Article

\title{
Grazer Functional Roles, Induced Defenses, and Indirect Interactions: Implications for Eelgrass Restoration in San Francisco Bay
}

\author{
Jeffrey T. Lewis and Katharyn E. Boyer * \\ Romberg Tiburon Center for Environmental Studies and Department of Biology, San Francisco State \\ University, 3150 Paradise Drive, Tiburon, CA 94920-1205, USA; E-Mail: jeffreythomaslewis@gmail.com \\ * Author to whom correspondence should be addressed; E-Mail: katboyer@sfsu.edu; \\ Tel.: +1-415-338-3751; Fax: +1-415-435-7120.
}

External Editor: Michael Wink

Received: 14 August 2014; in revised form: 21 October 2014 / Accepted: 18 November 2014 / Published: 26 November 2014

\begin{abstract}
Understanding the individual and interactive roles of consumer species is more than academic when the host plant is a subject of intense conservation interest. In a mesocosm experiment, we compared effects of common invertebrate grazers in San Francisco Bay seagrass (Zostera marina, eelgrass) beds, finding that some species (a native opisthobranch, Phyllaplysia taylori; a native isopod, Idotea resecata; and an introduced gastropod, Ilyanassa obsoleta) enhanced eelgrass growth through removal of epiphytic algae, as is often predicted for small invertebrate grazers on seagrasses, while one (an introduced caprellid amphipod, Caprella cf. drepanochir) had neutral effects. In contrast, the putatively-introduced gammaridean amphipod, Ampithoe valida, had strong negative effects on eelgrass (in addition to epiphytes) through consumption, as we had previously observed in the field during restoration programs. We tested whether other common grazer species could influence the effects of the eelgrass-grazing Ampithoe, and found that Idotea induced production of phenolic compounds and limited eelgrass damage by Ampithoe, without affecting Ampithoe abundance. These results have implications for restoration strategies, and contribute to a growing awareness of the importance of trait-mediated indirect grazer interactions through grazer-induced changes in plant traits, providing the first example in a seagrass system.
\end{abstract}


Keywords: assembly; induction; priority effect; indirect interaction; phenolic; restoration; invasive species; Ampithoe valida; Idotea resecata; Zostera marina

\section{Introduction}

Small invertebrate grazers are well known for their key roles in energy transfer to higher trophic levels, with important influences on the structure and functioning of both terrestrial and aquatic habitats [1]. As such, they have been subjects of intense study in community ecology, both in pursuit of basic understanding and in application to management programs. As grazer assemblages can be species-rich and taxonomy can be uncertain, it is common to partition them into functional groups, which can be useful as indicators of ecosystem quality, providing early warning of degradation or an assessment of recovery trajectory [2]. However, a more detailed understanding of how individual grazer species act and interact can be important in revealing functional subtleties that matter greatly to host plant morphology, phenology, chemistry, and other characteristics [3].

On seagrasses, marine angiosperms distributed globally in shallow coastal zones, small invertebrate grazers (mesograzers) often consume a coating of epiphytic algae, which otherwise can block light to plant leaves and limit nutrient uptake from the water column [4,5]. In a flurry of studies during the early 1980 s, this phenomenon was documented for a variety of mesograzer species across a broad geographic range, including the gastropods Bittium varium in Chesapeake Bay [6] and Littorina neglecta in Nova Scotia [7], and the isopod Idotea chelipes in the Netherlands [8]. Grazing of epiphytic algae can enhance the growth of seagrasses, in some cases proving a more important factor than the bottom-up effect of nutrient loading [9]. This has been supported by recent field experiments showing that mesograzers exert a strong positive effect on seagrass biomass through effective removal of epiphytic algae even under nutrient enriched conditions [10-12]. However, mesograzer species within an assemblage can have a range of effects on seagrass biomass, from beneficial to detrimental [13-16], even among closely related groups [17].

Although the roles of individual mesograzers are well known in some seagrass systems, interspecific interactions among mesograzer species that could affect seagrass responses or be mediated by them are poorly understood. Seagrasses may produce chemical deterrents in response to herbivory, including phenolic acids. These are a structurally diverse, broad category of chemical compounds that may defend against herbivory, as well as reduce biofouling and disease [18,19]. Several studies have demonstrated a negative correlation between concentration of phenolic compounds in seagrass and herbivory on it [20,21]. On marine algae, invertebrates have been found to induce defenses, which can influence interspecific competition among herbivores; e.g., grazing by the gastropod Littorina obtusata induces a defense response in the brown alga Fucus vesiculosus, reducing palatability to several other grazer species [22]. There has not yet been a seagrass example of such trait-mediated grazer-grazer interaction through induction of a defense response; however, simulated grazing induces a compensatory growth response in the seagrass Posidonia oceanica [23] and grazing by urchins can increase phenolic compounds in Thalassia testudinum and Halodule wrightii [24]. 
The effects and interactions of grazers on seagrasses are important to understand in part because these plants form highly valued habitats that are threatened worldwide. Seagrasses accrete and stabilize sediment, reduce turbidity, and attenuate flow of water [25]. Seagrass beds provide structure used as nursery habitat by juveniles of various shellfish and finfish species [26] and sequester an enormous amount of carbon [27]. Globally, seagrass beds are in decline due to a variety of anthropogenic impacts, particularly increases in water turbidity and eutrophication [28-30]. Successful conservation and restoration programs could benefit from knowledge of the contributions of grazers to seagrass growth, and might actively manage to encourage conditions that maximize positive effects.

In San Francisco Bay, California (USA), eelgrass (Zostera marina) forms monotypic beds that cover 1500 hectares [31]. As in other regions throughout the northern hemisphere where this species occurs [32], eelgrass in San Francisco Bay is highly valued as habitat and for carbon storage, water quality and sediment stabilization functions, but is threatened by a number of past and current impacts. Managers and scientists recently set goals to increase acreage by approximately 3000 hectares through restoration [33]. In order to make restoration efforts as efficient and effective as possible, it will be advantageous to understand factors that affect the success of restoration projects [34].

San Francisco Bay is one of the most highly invaded estuaries in the world [35] and the vast majority of individual mesograzers in the eelgrass beds are introduced species [36]. Little is known about the effects of mesograzers in these beds, although one species, the amphipod Ampithoe valida (hereafter referred to as Ampithoe), has been observed to feed on eelgrass tissues in addition to epiphytic algae and macroalgae [37,38], while it is not known to consume eelgrass elsewhere in its range (e.g., Chesapeake Bay [39]). Its consumption of both leaves and developing fruits can disrupt efforts to collect eelgrass propagules for restoration projects [34,37].

In this study, we conducted a mesocosm experiment to compare the effects of some of the most common mesograzer species in San Francisco Bay eelgrass beds, including both native and introduced grazers, on eelgrass epiphytes and on eelgrass biomass, shoot lengths, and production of phenolic compounds. Based on field observations, we hypothesized that only Ampithoe would have a negative impact on eelgrass through consumption, and thus that it would be the only species that might induce production of phenolic compounds. In a second phase of the experiment, we determined whether prior establishment of other grazers could influence the abundance or effects of Ampithoe added later, expecting that the other species could interfere with Ampithoe feeding on eelgrass or alternatively that prior reduction in epiphytes might increase its eelgrass consumption. We also wished to understand which grazers are likely to arrive at a newly established restoration site and whether the source of eelgrass used in restoration has an effect on recruitment of different species; hence, we conducted a field experiment evaluating early establishment of mesograzers on two source populations of eelgrass. Together, these mesocosm and field experiments were used to inform basic understanding of the roles of grazers in eelgrass habitats in San Francisco Bay, as well as management considerations for optimizing eelgrass establishment and persistence in restoration settings.

\section{Materials and Methods}

This study focused on five epifaunal grazer species that are common to San Francisco Bay eelgrass beds. First, Ampithoe valida is a gammaridean amphipod first documented in San Francisco Bay in 1941 
and presumed introduced [40]. Preliminary DNA sequence data from the mitochondrial gene COI support the introduction of a US Atlantic coast lineage [41] but also reveal a cryptic lineage that appears to be native to the Bay [42]. Second, Caprella cf. drepanochir is an introduced caprellid amphipod native to the east coast of Asia and most likely introduced through shipping [43]. Third, Ilyanassa obsoleta is an introduced prosobranch gastropod native to the east coast of North America and introduced in the early twentieth century in association with aquaculture [44]. Fourth, Phyllaplysia taylori is a native opisthobranch gastropod, and fifth, Idotea resecata is a native isopod. All species were identified using the Light and Smith Manual [45] and are referred to hereafter by generic names.

\subsection{Mesocosm Experiment}

We conducted a mesocosm experiment in two phases. Phase 1 tested the effects of individual grazer species on eelgrass, epiphytic algae, and phenolic concentrations. Phase 2 addressed the potential for individual grazer species to modify the abundance or effects of Ampithoe.

Eelgrass was collected from along the shore of Bay Farm Island in Alameda, California $\left(37^{\circ} 43^{\prime} 41^{\prime \prime} \mathrm{N}\right.$, $\left.122^{\circ} 14^{\prime} 52^{\prime \prime} \mathrm{W}\right)$. After collection, shoots were transported to San Francisco State University's Romberg Tiburon Center for Environmental Studies (Tiburon, CA, USA) and cleaned of all visible invertebrates and algae by agitation in a series of freshwater rinses [36], then trimmed to $60 \mathrm{~cm}$ aboveground and 10 $\mathrm{cm}$ rhizome lengths. Each mesocosm was a $22 \mathrm{~L}$ translucent plastic tank that individually received flow-through filtered bay water (drawn from San Francisco Bay at 12-m depth, $90 \mathrm{~m}$ from shore) and aeration via an aquarium bubbler. Excess water flowed out of the tank through a pipe in the upper portion of the tank; this pipe was blocked with a layer of 0.9-mm mesh to prevent escape of grazers. Two layers of fiberglass window screen with were placed over tops of tanks to reduce light levels to approximate the turbid conditions of San Francisco Bay. Each tank was planted with three eelgrass shoots, each in a separate $0.25 \mathrm{~L}$ tub filled with clean Felton sand from a soil supplier (American Soil Products, San Rafael, CA, USA).

We aimed to achieve a high level of replication $(n>20)$, and space limitations led us to initiate a series of temporal blocks over the period of July 2010 to December 2011 (see Appendix for list of dates). Each block contained one of each mesograzer treatment (see below for stocking densities) and one no-grazer control. Tanks colonized by unintended grazer species or otherwise compromised (e.g., by an interruption of baywater flow or a leaking tank) were dropped and there were brief periods in which one grazer was not available, leading to small overall differences in replication among the treatments. In order to control for the asynchronous initiation of experimental blocks, all measurements were standardized to the no-grazer control in the same temporal block; if a control tank was lost, the entire block associated with that control was eliminated from the study.

To begin Phase 1 of the experiment, each tank was stocked with one of the five grazer species in numbers calculated to result in approximately equal dry mass: 100 Ampithoe, 175 Caprella, 12 Idotea, 3 Ilyanassa, or 3 Phyllaplysia. These numbers are well within the measured ranges of field abundances for all species. In San Francisco Bay eelgrass beds, Ampithoe has been found at densities of over 100 per shoot, Caprella has been found in densities of around 250 per shoot and Idotea, Illyanassa, and Phyllaplysia are observed in densities of at least dozens per shoot $[36,37,46]$. All individual grazers placed in tanks were adults. Each temporal block of the experiment ran for fifteen days, at which point 
one eelgrass shoot was removed from the tank. The total aboveground length of this shoot was recorded and all epiphytic algae were scraped from it carefully using a razor blade. Eelgrass and algal samples were dried to a constant mass for 48 hours, then weighed. Eelgrass tissue was finely ground with a mortar and pestle and $6.0 \mathrm{mg}$ was placed into a $70 \%$ methanol solution for extraction. Levels of phenolic compounds in the methanol solution were measured using a modification of the colorimetric Folin-Ciocalteu process [47,48] with samples read at $760 \mathrm{~nm}$ using a Thermo Spectronic Genesys 20 spectrometer. Caffeic acid was used as a standard as it is the most abundant phenolic compound in eelgrass [49].

For eelgrass length, dry mass, and phenolic concentration, and epiphytic algal dry mass, measurements for each treatment tank were expressed as a proportion of the no-grazer control from the same temporal block. The epiphytic algal dry mass and phenolic concentration data were natural-log transformed to achieve an approximately normal distribution. A 95\% confidence interval was then calculated to permit assessment of grazer effects relative to the no-grazer controls; intervals that did not overlap with a value of one (or zero if log-transformed) were considered evidence of significant grazer effects.

Following Phase 1 of the experiment, we used Principal Component Analysis (PCA) on standardized data as a way to summarize relationships among the response variables and the impact of different mesograzer species, and to explore possible temporal patterns. Frequency distribution histograms and Quantile-Quantile plots were used to assess kurtosis and skewness in the data. The Box-Cox family of power transformations was used to minimize skewness as evaluated by D'Agostino tests: the relative mass data were square root transformed while Lambda values of $0.9,0.14$ and -0.13 , respectively, were used to transform relative length, mass of epiphytic algae, and concentration of phenolic compounds.

Phase 2 of the experiment addressed the degree to which established mesograzer populations might influence Ampithoe abundance or effects. Immediately following removal of the shoot on the fifteenth day at the end of Phase 1, 100 adult Ampithoe were added to each tank already established with one of the other four grazer species or to the no-grazer control. Tanks that started with Ampithoe during Phase 1 were eliminated from Phase 2 of the mesocosm experiment. Because Ampithoe was added to all tanks during this phase, the four previously established grazer species functioned as the treatments, in comparison to the tanks to which only Ampithoe had been added in Phase 2. After 35 more days, tanks were drained and all mesograzers and eelgrass were removed. Mass of eelgrass was determined as above and Ampithoe were preserved in ethanol and counted under a dissecting microscope. Final dry mass of eelgrass and number of Ampithoe were expressed as the difference between each treatment tank and its corresponding control (the tank with only Ampithoe added to the previous no-grazer control) from the same temporal block. A 95\% confidence interval was then calculated to compare each previously established grazer treatment to the control; intervals that did not include zero were considered to be evidence of a significant effect of the previously established grazer treatment on eelgrass mass or Ampithoe counts.

\subsection{Field Experiment}

We conducted a field experiment from June to September of 2011, simulating a newly planted restoration site to evaluate the composition and abundance of mesograzer species recruiting within the first few months. On 29 June 2011, eelgrass was collected from two donor populations: Point San Pablo, 
a bed on an offshore, sandy shoal in the San Pablo Bay region of San Francisco Bay $\left(37^{\circ} 58^{\prime} 28^{\prime \prime} \mathrm{N}\right.$, $\left.122^{\circ} 25^{\prime} 04^{\prime \prime} \mathrm{W}\right)$, and Point Molate, a nearshore bed in the Central Bay region ( $\left.37^{\circ} 56^{\prime} 36^{\prime \prime} \mathrm{N}, 122^{\circ} 24^{\prime} 45^{\prime \prime} \mathrm{W}\right)$ with much higher silt content [34]. The latter population had been grown in a culture tank at the Romberg Tiburon Center for several years. Eelgrass from both sources was cleaned of visible invertebrates in a series of freshwater rinses and trimmed to a uniform shoot and rhizome length as in the mesocosm experiment. On 30 June 2011, shoots from both donor populations were transplanted to bare mudflat off of San Rafael, California $\left(37^{\circ} 56^{\prime} 36^{\prime \prime} \mathrm{N}, 122^{\circ} 24^{\prime} 45^{\prime \prime} \mathrm{W}\right)$ within 50 or $100 \mathrm{~m}$ of a small $\left(<150 \mathrm{~m}^{2}\right)$, restored eelgrass plot planted in 2007. The nearest other eelgrass beds were a 0.02 hectare restored bed $>2 \mathrm{~km}$ away, and several natural beds on the order of 100+ hectares in size, all at least $5 \mathrm{~km}$ across the bay. In previous research, we have observed all mesograzer species used in this experiment to occur naturally in this region except for Illyanassa, which is more abundant in the southern portion of San Francisco Bay [45]. Shoots were transplanted into six blocks, three that were $50 \mathrm{~m}$ from the small, restored bed and three that were $100 \mathrm{~m}$ from it. Each block contained four plots, two with plants from each source population (for a total of 12 plots from each donor). Each $0.25 \mathrm{~m}^{2}$ plot was planted with five independent eelgrass shoots, with one shoot near each corner of the plot and one in the center. Bare root shoots were anchored to bamboo stakes using paper-coated wire twist ties, a method commonly used in San Francisco Bay restoration projects [34].

On 27 September 2011, all shoots were removed from each plot. Shoots were removed by swiftly inserting the shoot into a plastic bag under the water then detaching the rhizome. Invertebrates were removed from each shoot using a series of freshwater rinses filtered through a 500-micron sieve, then were preserved in ethanol, identified, and counted. Each shoot was measured, dried, weighed, and analyzed for total phenolic content as in the mesocosm experiment.

Tests to determine if distance from the small restoration site $(50$ or $100 \mathrm{~m}$ ) or block position (six blocks) mattered for any of the response variables found no significant differences (t-tests, ANOVA, Kolmogorov-Smirnov tests; all $p>0.12$ ); therefore, data were pooled and source population was used as the sole basis of comparison. Nine of the 24 plots contained no surviving eelgrass shoots and these were counted as zeros in a comparison of shoot density using the Kolmogorov-Smirnov test, but were excluded from all other comparisons. Shoot length and mass (log-transformed) and phenolic concentration were compared among source populations using unequal variance (Welch) t-tests [50].

As only two species, Ampithoe and Sinocorophium alienense, made up 98\% of the individual grazers recruiting to the newly planted eelgrass (see results), these were the only species assessed by source population. Length measurements were made on a subsample of ten individuals of each of these two species. Counts were made relative to the mass of eelgrass by dividing the number of each grazer species in a given plot by the total dry mass of eelgrass in that plot. These relativized counts (log-transformed) of Ampithoe on the two source populations were compared using an unequal variance t-test. Abundances of Sinocorophium could not be adequately transformed and were compared using a KolmogorovSmirnov test. 


\section{Results and Discussion}

\subsection{Mesocosm Experiment}

During the hundreds of hours of observing these mesograzer species over the course of this experiment, no intraspecific or interspecific predation was observed. As expected, Ampithoe was frequently observed to feed directly on eelgrass, by consuming tissues along the leaf margins. In addition, Idotea was occasionally observed to consume eelgrass by grazing on the surface of the leaves.

During Phase 1 of this experiment, presence of Ampithoe led to significant reductions in eelgrass mass as expected, while Caprella had no effect, and presence of the other three species, Idotea, Ilyanassa, and Phyllaplysia, all led to significant increases in biomass (Figure 1a). Shoot length showed the same patterns, except that Phyllaplysia's tendency to enhance length was not significant (Figure 1b).

Figure 1. Effects of grazer species on eelgrass (a): mass and (b) shoot length at the end of Phase 1 of the mesocosm experiment. Error bars are 95\% CI. Asterisks indicate significant effects as determined by confidence intervals that do not overlap with the control value of 1 . Species and sample sizes were AV = Ampithoe valida $(n=26), \mathrm{CD}=$ Caprella drepanochir $(n=23)$, IO = Ilyanassa obsoleta $(n=23)$, IR $=$ Idotea resecata $(n=26)$, and $\mathrm{PT}=$ Phyllaplysia taylori $(n=24)$.

(a)

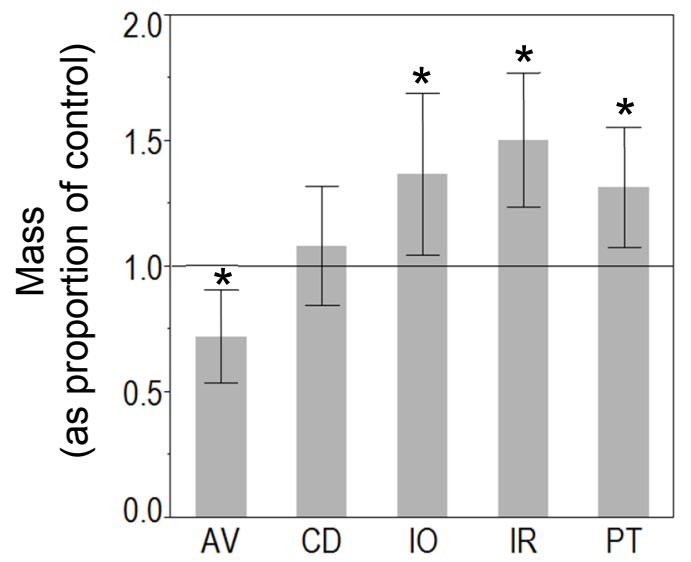

(b)

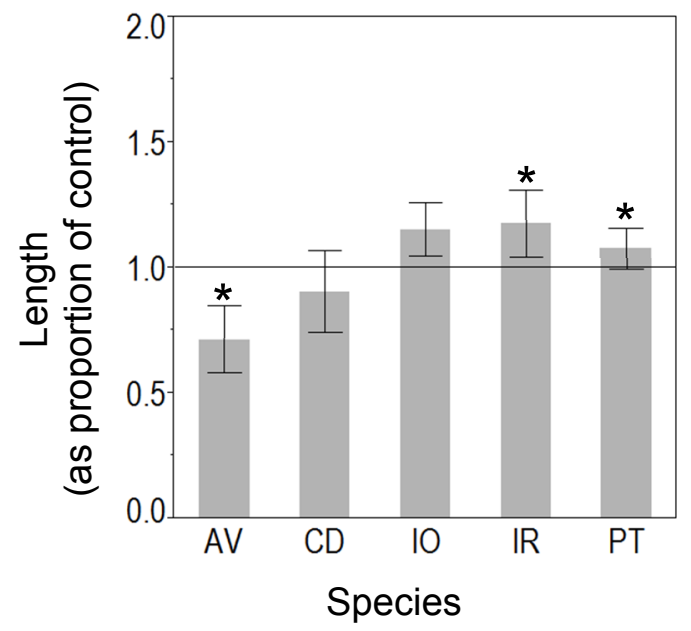

All grazers except for Caprella significantly reduced epiphytic algal biomass (Figure 2a), suggesting this was the mechanism for increased eelgrass growth in the presence of those species. Surprisingly, 
total phenolic compound concentration increased significantly relative to controls only in tanks with Idotea present (Figure 2b). Though we had predicted that eelgrass consumption by Ampithoe might trigger production of plant defenses, it had no effect on phenol concentrations.

Figure 2. Effects of grazer species on (a) epiphytic algae mass per mass of eelgrass and (b) eelgrass phenolic content, as a proportion of the control, at the end of Phase 1 of the mesocosm experiment. Species abbreviations and error bars as in Figure 1. Untransformed algae data are shown in (a) but significance $\left(^{*}\right)$ was determined on log-transformed data in comparison to the log-transformed control value of zero: AV (95\% CI: $-1.9103--0.7433$, $n=19)$, CD (95\% CI: $-1.2749-0.0049, n=18)$, IO (95\% CI: $-1.7691--0.7167, n=18)$, IR (95\% CI: $-1.9702--0.9591, n=20)$, and PT (95\% CI: $-1.8273--0.5038, n=17)$. Similarly, untransformed phenolic concentration data are shown in (b) but significance (*) was determined on log-transformed data: AV (95\% CI: $-0.2551-0.1921, n=26), \mathrm{CD}(95 \%$ CI: $-0.2141-0.2861, n=22)$, IO (95\% CI: $-0.2004-0.1406, n=23)$, IR (95\% CI: $0.1336-0.5441, n=26)$, and PT (95\% CI: $-0.1799-0.2587, n=26)$. In both cases, the untransformed data showed the same patterns.

(a)

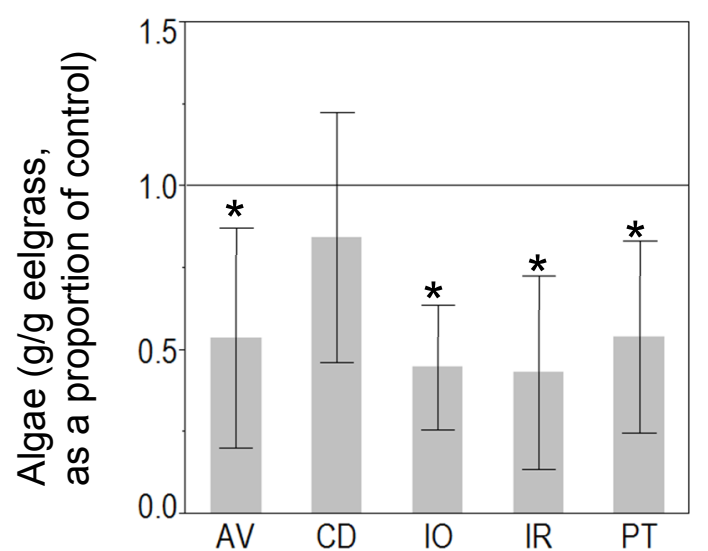

(b)

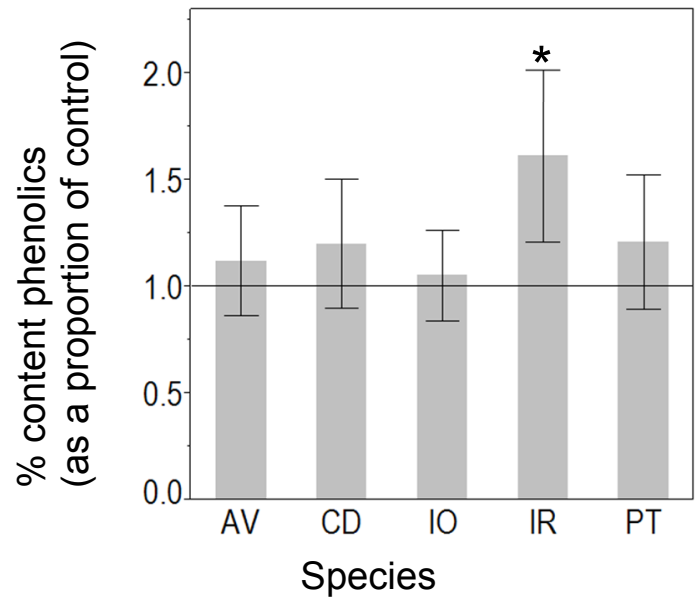

Principal Components Analysis illustrated some of the major trends described above across the temporal blocks of the experiment (Figure 3) and examined whether effects of grazer species were related to season. The first three components of the PCA explained $93.8 \%$ of the inertia in the initial dataset, with the first component (PC1, 49.4\% of projected inertia) negatively correlated with relative length and mass, PC2 (23.6\%) negatively correlated with epiphytic algal mass, and PC3 (20.8\%) 
negatively correlated with eelgrass phenolic compound concentration. Data were color-coded and ellipses were drawn to show patterns in grazer species treatment or season. Ampithoe, plotting toward the right on the PC1 axis (Figure 3, $x$-axis in the "Species" plots, middle) is the only species that obviously had a negative impact on eelgrass mass and length in the majority of temporal experimental blocks. In addition, Idotea presence showed a clear correlation with elevated phenolic concentrations (lower left corner of the PC1/PC3 "Species" plot, Figure 3b, middle). While there was variability in the data set, there was substantial overlap among seasons and little difference in pattern (Figure 3, "Seasons" plots at bottom), suggesting minimal differences in grazer effects attributable to seasonal timing of the temporal blocks.

Figure 3. Results of Principal Components Analysis following Phase 1 of the mesocosm experiment. In (a) Principal Component (PC) 1 is negatively correlated with eelgrass length and mass and PC 2 is negatively correlated with epiphytic algal mass. In (b) PC 3 is negatively correlated with phenolic concentration. The lower plots show the data color coded by species (abbreviations as in Figure 1) or seasons. Ellipses grouping the data encompass $\sim 67 \%$ of the points.

(a)

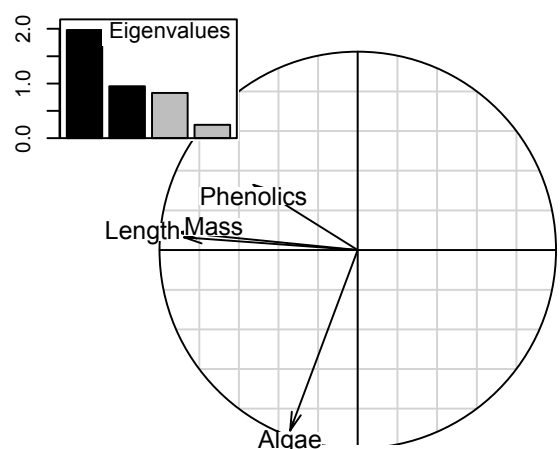

PC1 (49.4\%) and PC2 $(23.6 \%)$ (b)

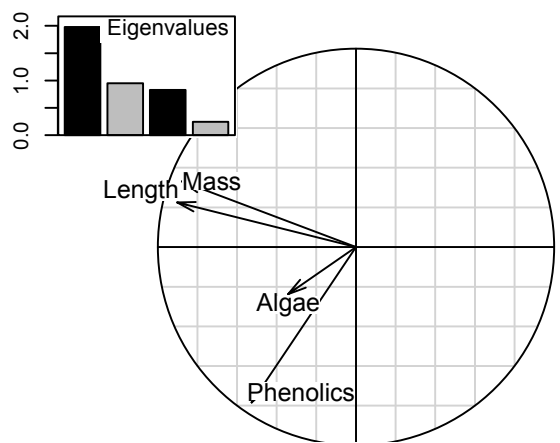

PC1 (49.4\%) and PC3 (20.8\%)

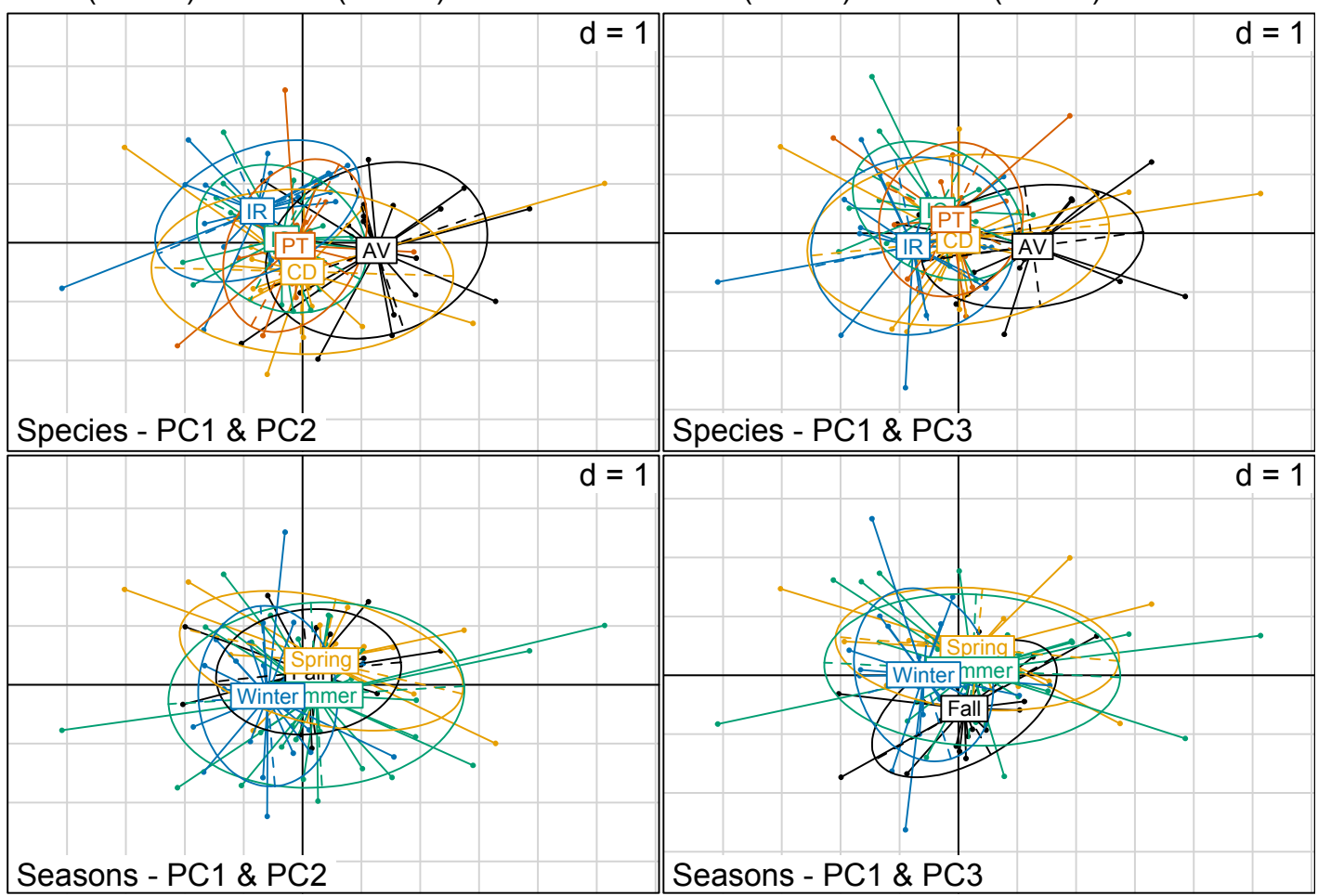


At the end of Phase 2, the abundance of Ampithoe in tanks previously stocked with the other grazer species was no different than in the control tanks that began with no grazers (Figure 4a). Final Ampithoe abundances were highly variable, with recent reproduction evident in a portion of the tanks across grazer treatments (smaller individuals $\sim 6 \mathrm{~mm}$ in addition to individuals up to $10.7 \mathrm{~mm}$ ). Notably, thirty-five days after introduction of Ampithoe, the final mass of eelgrass significantly increased if tanks were initially stocked with Idotea (Figure 4b), even though final abundance of Ampithoe was comparable across grazer treatments.

Figure 4. Results from Phase 2 of the mesocosm experiment (addition of Ampithoe valida to tanks already established with the other species or to the previous no-grazer controls) showing (a) final number of $A$. valida and (b) final mass of eelgrass. Error bars are 95\% confidence intervals. Asterisks indicate confidence intervals that do not overlap with the control value of zero. Species abbreviations as in Figure 1. Sample sizes were: CD: $n=18$, IO: $n=19$, IR: $n=19$, and PT: $n=20$.

(a)

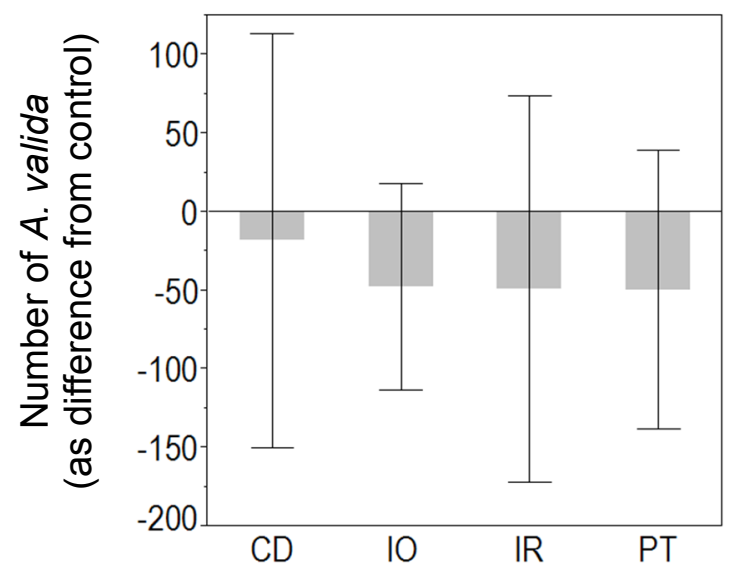

(b)

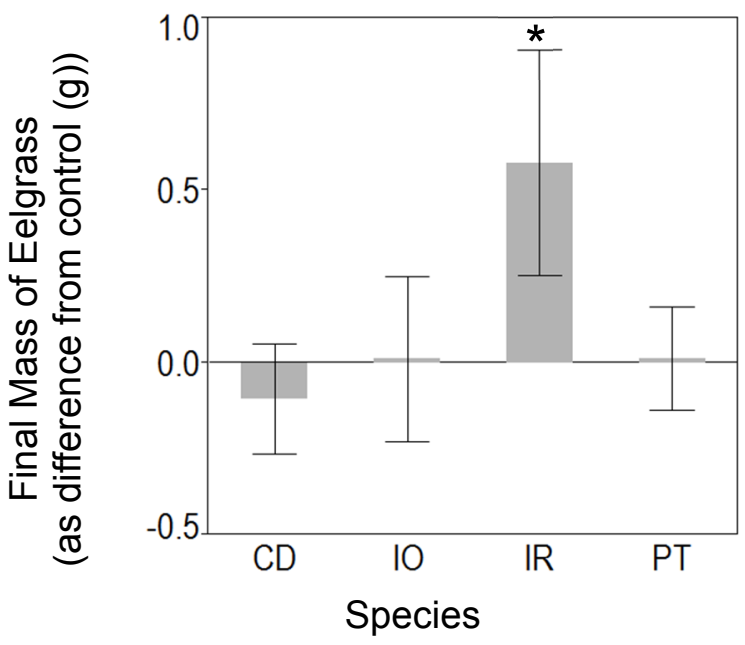

Generally, the effects of individual grazers on plant and algae responses were concordant with expectations, as summarized in Figure 5. The positive effect of Idotea and Phyllaplysia on eelgrass growth through removal of epiphytic algae is consistent with previous findings in Padilla Bay, Washington [51] and Bodega Bay, California [52]. We also found the introduced Ilyanassa to produce a similar increase in eelgrass mass. This contrasts with our expectation of negative effects of Ilyanassa based on field observations of these snails weighing down plants in the water column and also coating 
eelgrass blades with large quantities of eggs (which could both affect light availability), neither of which we observed here. In our experiment, Ilyanassa and Phyllaplysia appeared to be functionally redundant in terms of their positive impacts on eelgrass, which likely stemmed from their negative effects on epiphyte mass. Although Idotea exerted a similar effect on eelgrass and epiphytes during Phase 1 of the mesocosm experiment, it cannot be considered functionally equivalent to the other grazers because of its unique interactions with Ampithoe during Phase 2. Observations during the course of the mesocosm experiment support the contention that Caprella is primarily a suspension feeder, foraging food particles from the water column. Its presence did not influence Ampithoe abundance or effects in Phase 2, but we note that effects in the field may differ; i.e., another study found Ampithoe's negative effects on eelgrass to increase when both Caprella and a common predator, the bay pipefish (Sygnathus leptorhynchus) were present, presumably due to greater predation susceptibility of Caprella [38].

Figure 5. Conceptual diagram of interactions among grazer species, eelgrass, and epiphytic algae as observed in the mesocosm experiment. Solid black lines indicate a negative effect of one species on another. Dashed red lines indicate an indirect positive effect of one species on another. The dotted orange line indicates the reduction in Ampithoe's negative effects on eelgrass with Idotea present, which may be mediated by Idotea-induced changes in eelgrass palatability. All photos by the authors. Organisms not shown to scale.

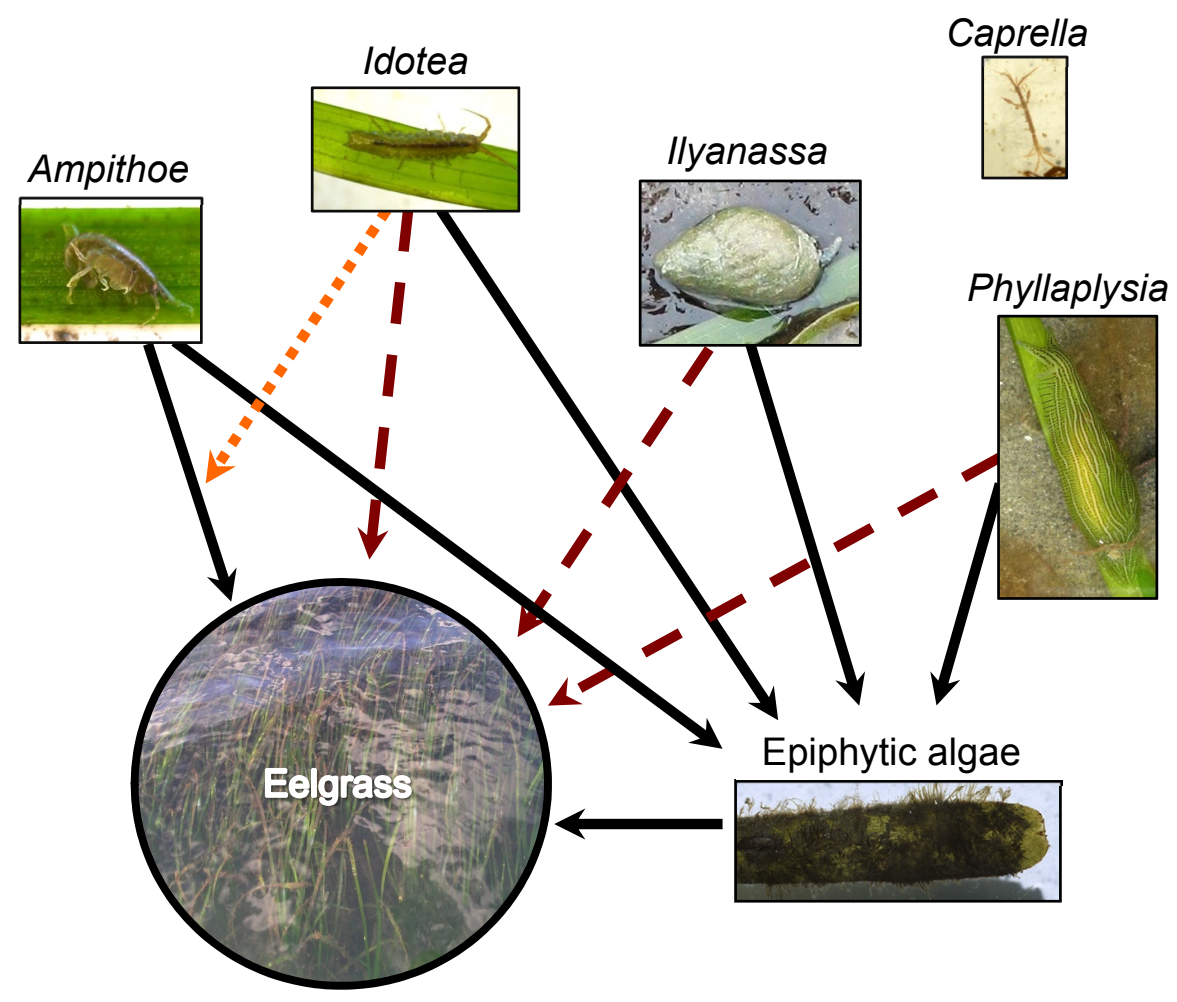

The significantly higher final mass of eelgrass relative to the controls in tanks that were initiated with Idotea and subsequently invaded with Ampithoe suggests that there was an interaction between the two species that reduced Ampithoe's consumption of eelgrass. Because Idotea did not affect the final abundance of Ampithoe, it is unlikely that this took the form of direct predation, and during extensive observation over the course of Phase 2, Idotea did not show aggression toward Ampithoe. Instead, the interaction between Idotea and Ampithoe is likely indirect, through induction of a physiological response 
in eelgrass. While tanks with Ilyanassa, Idotea, and Phyllaplysia all showed an increase in the size of eelgrass shoots during the initial single grazer period, only those containing Idotea were associated with an increase in concentration of phenolic compounds. In addition to consuming epiphytic algae, Idotea consumes some eelgrass, as we observed and as seen in other studies [21,51,52]. This limited herbivory appears to induce a chemical defensive response in the eelgrass in the form of increased production of phenolic compounds. Such an induction of defenses has precedence in studies of other marine isopods; e.g., herbivory by Idotea baltica was found to induce a defense response in the brown alga Fucus vesiculus, which reduced subsequent herbivory by the isopod [53]. In our study, phenol content ranged from $0.2 \%$ to $1.2 \%$ dry mass in the controls, and as high as $2.4 \%$ in the Idotea treatment. Control concentrations were within the range surveyed in Zostera marina $(0.2 \%-1.5 \%$ dry mass $[21,54-56]$, also see Figure 6 below); no other studies have determined phenol concentrations that deter grazers on this plant, but experimental exposure to wasting disease (caused by infection with the marine slime mold Labyrinthula zosterae) can lead to concentrations in the range of $1.7 \%-3.4 \%$ dry mass $[56,57]$.

Figure 6. Effects of eelgrass source in the field experiment on eelgrass (a): shoot density, (b) dry mass, (c) total phenolic concentration, and (d) abundance of Ampithoe valida. Error bars are $95 \%$ confidence intervals. Different letters indicate statistically significant differences. Sources were PM = Point Molate and PSP $=$ Point San Pablo. $n=10$ except for PSP in (b-d), where $n=5$ (only those plots with surviving shoots).

(a)

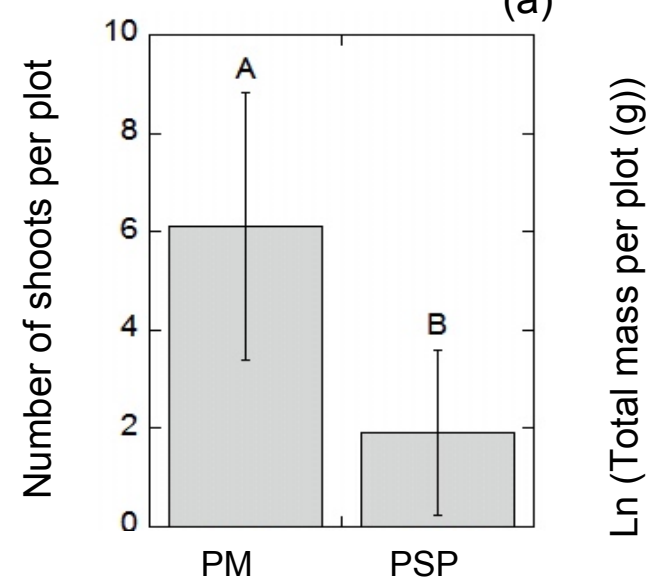

(c)

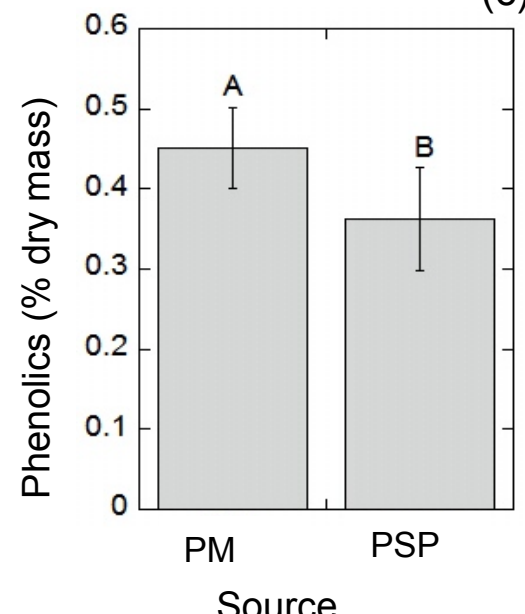

(b)

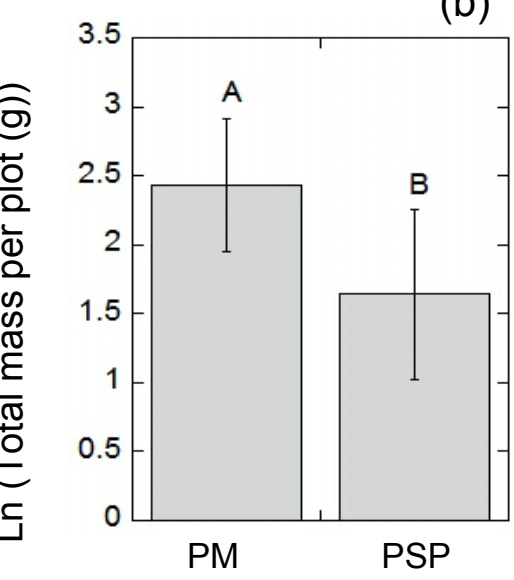

(d)

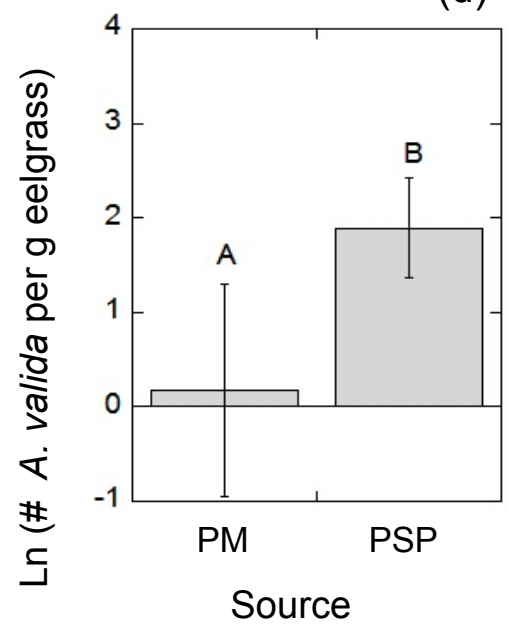


That only Idotea increased eelgrass production of phenolic compounds among the range of grazers in our study may relate to this isopod's specific feeding mode. While all the grazers except the suspension feeding Caprella removed epiphytes, Idotea also appeared to remove eelgrass tissue from the surface of the leaves. Other studies have found variation in defense responses resulting from differences in feeding modes; e.g., the gastropod Littorina obtusata excavated brown algal tissues rather than removing entire portions of tissue like L. littorea, and only the former reduced palatability of the algae to multiple species [22]. Similarly, we found Ampithoe damage to leaf margins and removal of whole portions of eelgrass tissue to not induce a defense response in the plant. In contrast, anti-herbivore responses in several algal species have been induced by other amphipods [58], including the congener Ampithoe longimana [59].

\subsection{Field Experiment}

Point Molate plots had significantly higher shoot densities $(p=0.0498)$ (Figure 6a) and total aboveground dry mass of eelgrass $(p=0.0256)$ (Figure $6 \mathrm{~b}$ ) than Point San Pablo plots. However, no significant difference in shoot length was observed between the two sources ( $p=0.5329$; not shown). Point Molate eelgrass had significantly higher concentrations of phenolic compounds than Point San Pablo plants $(p=0.0098)$, though concentrations in both were relatively low (Figure $6 \mathrm{c}$ and see range described above). Of all invertebrates counted on plants harvested at the end of the three-month experiment, $73.7 \%$ were Ampithoe (mean length $=5.1 \mathrm{~mm}$ ), 24.1\% were Sinocorophium alienense (mean length $=2.7 \mathrm{~mm}$ ), and the remaining $\sim 2 \%$ were the isopod Gnorimosphaeroma oregonense, the decapod Hemigrapsus oregonensis, and a few individuals of other amphipod and nematode species. It is notable that none of the other common invertebrates observed in established eelgrass beds [36,44] recruited during this period, including the one species identified in our mesocosm experiment to induce chemical defenses and the three that grazed competing epiphytes to the benefit of eelgrass. Ampithoe was significantly more abundant in Point San Pablo plots than in Point Molate plots $(p=0.0079)$ (Figure 5d). There was no difference in abundance of Sinocorophium on plants from the two source populations ( $p=0.5488$; not shown), nor would we expect it to respond to food quality, as members of its family are deposit feeders [60].

San Francisco Bay eelgrass populations show a significant degree of genetic differentiation among different regions including among the two source populations used in this experiment [61], and this may influence phenotypic differentiation. In other studies, source plant genotype has been demonstrated to influence the degree to which herbivory affects the successful establishment of plant restorations [62]. Further, genotype has been demonstrated to affect the degree to which herbivores directly consume eelgrass [21]. In the case of our field experiment, it is possible that more similar soil conditions between Point Molate and the simulated restoration site (both higher in fine particles than Point San Pablo, which could affect nutrient availability as well as light due to higher potential for resuspension [34]), led to greater suitability for plants adapted to those conditions. However, it is difficult to determine whether differences in donor source performance were a result of genetic differentiation or a result of differences in initial environment of the donor site.

Although higher phenolic concentrations in Point San Pablo plants could have contributed to reduced Ampithoe abundances in view of our mesocosm results, other unmeasured factors such as nutrient 
concentrations or ratios also could have contributed to differential colonization of Ampithoe among source populations [21]. Others have found no relationship between higher concentrations of phenolic compounds in seagrass tissue and resistance to herbivory; e.g., grazing by the urchin Lytechinus variegatus on two species of seagrass, Thalassia testudinum and Halodule wrightii, induced an increase in phenolic compounds in both, but did not reduce subsequent herbivory [24]. In addition to defense against herbivory, phenolic compounds play a role in a variety of physiological processes. One function of phenolic compounds is as a precursor to the production of structural tissues; one study that actually found reductions in concentrations of phenolic compounds following simulated grazing on Posidonia oceanica posited that this reduction was due to these precursors having been rapidly put into use in a compensatory growth response [23]. Phenolic compounds, particularly caffeic acid, may be induced in eelgrass as a defense against wasting disease [56,63], which our observations suggest can be more prevalent at Point Molate than Point San Pablo eelgrass beds. Protection from pathogens is a role that phenolic compounds play in many other situations, including the induction of phenolic compounds to protect wounds on the common potato from infection by rot-producing bacteria [64]. Phenolic compounds are also important in shielding plants against damage from ultraviolet-B radiation damage $[65,66]$ and in some cases this may be of greater importance than the role these compounds play in defense against herbivory [67]. Interestingly, as grazer species remove epiphytic algae, eelgrass is exposed to greater amounts of ultraviolet-B radiation, potentially causing an increase in production of phenolic compounds for protection from ultraviolet-B radiation. Hence, it is possible that the increased phenolic content of eelgrass induced by Idotea in Phase 2 of our mesocosm experiment resulted, in part, from Idotea's efficiency in cleaning eelgrass of epiphytic algae. Regardless of whether Idotea's consumption of small amounts of eelgrass, its efficient removal of epiphytes, or some combination, induced phenolic compound production by Idotea, the observed result was defense against Ampithoe's damaging consumptive effects, an effect which could extend to field conditions in which Idotea is present or phenolic concentrations are otherwise elevated.

\section{Conclusions}

In this study, we tested the effects of common mesograzer species on eelgrass in San Francisco Bay, finding a range of effects from positive to neutral to negative. Although mesograzers on seagrasses have been shown to increase eelgrass growth through consumption of competing epiphytic algae (e.g., [11]), our results emphasize that the individual roles of mesograzers can be quite varied and thus that the ultimate outcome of their presence will depend on species composition and relative abundance over time and space. Common grazers in this system include both native and introduced species, and introduced status did not clearly relate to an outcome of positive or negative effects on eelgrass. Most notably, Ampithoe in San Francisco Bay, which preliminary data suggest represents a combination of native and introduced lineages [41,42], was shown to have net negative effects through direct eelgrass consumption that swamps its potential positive effects of epiphyte removal. Other grazers we tested, both introduced (a prosobranch gastropod) and native (an opisthobranch gastropod and an isopod), had positive effects on eelgrass through removal of competing epiphytes, and an introduced caprellid amphipod had neutral effects on eelgrass. 
Production of phenolic compounds in the presence of the native isopod Idotea, along with significantly increased eelgrass biomass despite the presence of Ampithoe, provides support for the hypothesis that Idotea-induced defenses limited Ampithoe's negative effects on eelgrass. Such a trait-mediated indirect interaction between grazers through grazer-induced changes in plant traits has not previously been observed in a seagrass system; however, this phenomenon may be common in competitive interactions between mandibulate insect species on land plants [3,68]. In addition, there are a growing number of examples of plant trait-mediated indirect competitive interactions among grazers in marine systems, including on cordgrass in salt marshes (congeneric planthoppers [69] or gastropods and planthoppers [70]), and on several species of brown algae (gastropods and isopods [53,71], isopods and amphipods [72], and congeneric gastropods [22]).

The results of this study show potential for application to eelgrass restoration in San Francisco Bay. First, several grazer species reduced epiphyte biomass on eelgrass and led to increased eelgrass growth, and particularly the natives Idotea and Phyllaplysia might be specifically targeted as species to transplant along with eelgrass or to culture and place in newly restored eelgrass beds. That we observed no recruitment of these species within three months of our field experimental transplant suggests that they may not arrive readily on their own. Second, the special ability of Idotea to reduce eelgrass herbivory by Ampithoe is a phenomenon that might also be exploited by restoration practitioners to improve the success of eelgrass restoration efforts. Eelgrass grown in a nursery setting could be inoculated with Idotea before planting or Idotea could be transplanted along with eelgrass in order to enhance resistance to Ampithoe herbivory in the vulnerable early stages of restoration. We caution that this application of our results should be further explored through experimental field-based tests of the efficacy and practicality of such a technique. Finally, the differences in growth characteristics, phenolic concentrations, and Ampithoe colonization on two transplanted eelgrass populations in a common garden field setting suggests that either genetic differentiation or persistence of traits induced by differences in donor source environment translate to differences in plant performance, a realization that warrants further exploration and consideration in selecting donor populations for restoration projects.

\section{Acknowledgments}

We thank Jonathon Stillman and Wim Kimmerer for advice and review throughout this research. Julien Moderan provided valuable assistance with the principle components analysis. Stephanie Kiriakopolos, Gwen Santos, Lindsey Carr and Laura Reynolds provided helpful advice on methods. Several volunteers contributed substantial time to the project, particularly Joseph Spaulding. Funding for this research was provided by the National Science Foundation-San Francisco State University Training in Ecology and Evolution (TREE) Fellowship, the California State University Council on Ocean Affairs, Science and Technology (COAST), and the Romberg Tiburon Center for Environmental Studies. We also thank the anonymous reviewers whose comments improved this paper.

\section{Author Contributions}

Both authors took part in experimental design, data analysis, and writing of manuscript. Jeffrey T. Lewis carried out the majority of field and laboratory data collection. 


\section{Appendix}

Table A1. List of dates on which temporal blocks of the mesocosm experiment began.

\begin{tabular}{cc}
\hline Temporal Block & Date Initiated \\
\hline 1 & $7 / 24 / 2010$ \\
2 & $8 / 2 / 2010$ \\
3 & $8 / 9 / 2010$ \\
4 & $8 / 14 / 2010$ \\
5 & $8 / 28 / 2010$ \\
6 & $9 / 2 / 2010$ \\
7 & $9 / 9 / 2010$ \\
8 & $9 / 19 / 2010$ \\
9 & $10 / 4 / 2010$ \\
10 & $11 / 15 / 2010$ \\
11 & $12 / 7 / 2010$ \\
12 & $12 / 29 / 2010$ \\
13 & $1 / 8 / 2011$ \\
14 & $1 / 20 / 2011$ \\
15 & $2 / 3 / 2011$ \\
16 & $2 / 8 / 2011$ \\
17 & $2 / 20 / 2011$ \\
18 & $3 / 1 / 2011$ \\
19 & $4 / 14 / 2011$ \\
20 & $5 / 9 / 2011$ \\
21 & $5 / 18 / 2011$ \\
22 & $6 / 2 / 2011$ \\
23 & $7 / 25 / 2011$ \\
24 & $8 / 16 / 2011$ \\
25 & $8 / 30 / 2011$ \\
26 & $9 / 14 / 2011$ \\
27 & $9 / 21 / 2011$ \\
\hline & \\
& \\
\hline &
\end{tabular}

\section{Conflicts of Interest}

The authors declare no conflict of interest.

\section{References and Notes}

1. Cyr, H.; Pace, M.L. Allometric theory: Extrapolations from individuals to communities. Ecology 1993, 74, 1234-1245.

2. Andersen, A.N.; Majer, J.D. Ants show the way Down Under: Invertebrates as bioindicators in land management. Front. Ecol. Environ. 2004, 2, 291-298.

3. Ohgushi, T. Indirect interaction webs: Herbivore-Induced effects through trait change in plants. Annu. Rev. Ecol. Evol. Systemat. 2005, 36, 81-105. 
4. Tomasko, D.K.; LaPointe, B.E. Productivity and biomass of Thalassia testudinum as related to water column nutrient availability and epiphyte levels-Field observations and experiemental studies. Mar. Ecol. Progr. 1991, 75, 9-17.

5. Sand-Jensen, K. Effect of epiphytes on eelgrass photosynthesis. Aquat. Bot. 1977, 3, 55-63.

6. Van Montfrans, J.; Orth, R.J.; Vay, S.A. Preliminary studies of grazing by Bitium varium on eelgrass periphyton. Aquat. Bot. 1982, 3, 75-89.

7. Robertson, A.I.; Mann, K.H. Population dynamics and life history adaptations of Littorina neglecta in an eelgrass meadow (Zostera marina L.) in Nova Scotia. J. Exp. Mar. Biol. Ecol. 1982; 63, 151-171.

8. Hootsmans, M.J.M.; Vermaat, J.E. The effect of periphyton grazing by three epifaunal species on the growth of Zostera marina L. under experimental conditions. Aquat. Bot. 1985, 22, 83-88.

9. Neckles, H.A.; Wetzel, R.L.; Orth, R.J. Relative effects of nutrient enrichment and grazing on epiphyte-macrophyte (Zostera marina L.) dynamics. Oecologia 1993, 93, 285-295.

10. Whalen, M.A.; Duffy, J.E.; Grace, J.B. Temporal shifts in top-down vs. bottom-up control of epiphytic algae in a seagrass ecosystem. Ecology 2013, 94, 510-520.

11. Reynolds, P.L.; Richardson, J.P.; Duffy, J.E. Field experimental evidence that grazers mediate transition between microalgal and seagrass dominance. Limnol. Oceanogr. 2014, 59, 1053-1064.

12. Moksnes, P.; Tryman, K.; Baden, S. Trophic cascades in a temperate seagrass community. Oikos. 2008, 117, 767-777.

13. Duffy, J.E.; MacDonald, K.S.; Rhode, J.M.; Parker, J.D. Grazer diversity, functional redundancy, and productivity in seagrass beds: An experimental test. Ecology 2001, 82, 2417-2434.

14. Holzer, K.K.; Rueda, J.L.; McGlathery, K.J. Differences in the feeding ecology of two seagrass-associated snails. Estuar. Coast. 2011, 34, 1140-1149.

15. Lewis, L.S.; Anderson, T.W. Top-down control of epifauna by fishes enhances seagrass production. Ecology 2012, 93, 2746-2757.

16. Ecklof, J.S.; Alsterberg, C.; Havenhand, J.N.; Sundback, K.; Wood, H.L.; Gamfeldt, L. Experimental climate change weakens the insurance effect of biodiversity. Ecol. Lett. 2012, 15, 864-872.

17. Best, R.J.; Stachowicz, J.J. Trophic cascades in seagrass meadows depend on mesograzer variation in feeding rates, predation susceptibility, and abundance. Mar. Ecol. Progr. 2012, 456, $29-42$.

18. Todd, J.S.; Zimmerman, R.C.; Crew, P.; Alberte, R.S. The antifouling activity of natural and synthetic phenol acid sulfate esters. Phytochemistry 1993, 34, 401-404.

19. Bennett, R.N.; Wallsgrove, R.M. Secondary metabolites in plant defense mechanisms. New Phytol. 1994, 127, 617-633.

20. Verges, A.; Becerro, M.A.; Alcoverro, T.; Romero, J. Variation in multiple traits of vegetative and reproductive seagrass tissues influences plant-herbivore interactions. Oecologia 2007, 151, 675-686.

21. Tomas, F.; Abbott, J.M.; Steinberg, C.; Balk, M.; Williams, S.L.; Stachowicz, J.J. Plant genotype and nitrogen loading influence seagrass productivity, biochemistry, and plant-herbivore interactions. Ecology 2011, 92, 1807-1817.

22. Long, J.D.; Hamilton, R.S.; Mitchell, J.L. Asymmetric competition via induced resistance: Specialist herbivores indirectly suppress generalist preference and populations. Ecology 2007, 88, 1232-1240.

23. Verges, A.; Perez, M.; Alcoverro, T.; Romero, J. Compensation and resistance to herbivory in seagrasses: Induced responses to simulated consumption by fish. Oecologia 2008, 155, 751-760. 
24. Steele, L., Valentine, J.F. Idiosyncratic responses of seagrass phenolic production following sea urchin grazing. Mar. Ecol. Progr. 2012, 466, 81-92.

25. Bos, A.R.; Bouma, T.J.; de Kort, G.L.J.; van Katwijk, M.M. Ecosystem engineering by annual intertidal seagrass beds: Sediment accretion and modification. Estuar. Coast. Shelf. Sci. 2007, 74, 344-348.

26. Heck, K.L.; Hays, G.; Orth, R.J. Critical evaluation of the nursery role hypothesis for seagrass meadows. Mar. Ecol. Progr. 2003, 253, 123-136.

27. Fourqurean, J.; Duarte, C.M.; Kennedy, H.; Marba, N.; Holmer, M.; Mateo, M.A.; Apostalaki, E.T.; Kendrick, G.A.; Krause-Jensen, D.; McGlathery, K.J.; et al. Seagrass ecosystems as a globally significant carbon stock. Nat. Geosci. 2012, 5, 505-509.

28. Short, F.T.; Wyllie-Echeverria, S. Natural and human-induced disturbance of seagrass. Environ. Conservat. 1996, 23, 17-27.

29. Orth, R.J.; Carruthers, T.J.B.; Dennison, W.C.; Duarte, C.M.; Fourqurean, J.W.; Heck, K.L.; Hughes, A.R.; Kendrick, G.A.; Kenworthy, W.J.; Olyarnik, S.; et al. A global crisis for seagrass ecosystems. Bioscience 2006, 56, 987-996.

30. Waycott, M.; Duarte, C.M.; Carruthers, T.J.; Orth, R.J.; Dennison, W.C.; Olyarnik, S.; Calladine, A.; Fourquerean, J.W.; Heck, K.L.; Hughes, A.R.; et al. Accelerating loss of seagrasses across the globe threatens coastal ecosystems. Proc. Natl. Acad. Sci. USA 2009, 106, 12377-12381.

31. Merkel and Associates, Inc. Baywide Eelgrass (Z. marina L.) Distribution and Status within San Francisco Bay: Program Development and Testing of a Regional Eelgrass Monitoring Strategy; California Department of Transportation: Sacramento, CA, USA, 2010.

32. World Atlas of Seagrasses; Green, E.P.; Short, F.T., Eds.; University of California Press: Berkeley, CA, USA, 2003.

33. State Coastal Conservancy. San Francisco Bay Subtidal Habitat Goals Report. State Coastal Conservancy: Oakland, CA, USA, 2010.

34. Boyer, K.E.; Wyllie-Echeverria, S. Subtidal Habitat Goals Project Report, Appendix 8-1: Eelgrass Conservation and Restoration in San Francisco Bay, Opportunities and Constraints. State Coastal Conservancy: Oakland, CA, USA, 2010.

35. Cohen, A.N.; Carlton, J.T. Accelerating invasion rate in a highly invaded estuary. Science 1998, 279, 555-558.

36. Carr, L.A.; Boyer, K.E.; Brooks, A.J. Spatial patterns of epifaunal abundance in San Francisco Bay eelgrass (Zostera marina) beds. Mar. Ecol. 2011, 32, 88-103.

37. Reynolds, L.K.; Carr, L.A.; Boyer, K.E. A non-native amphipod consumes eelgrass inflorescences in San Francisco Bay. Mar. Ecol. Progr. 2012, 451, 107-118.

38. Carr, L.A.; Boyer, K.E. Variation at multiple trophic levels mediates a novel seagrass-grazer interaction. Mar. Ecol. Progr. 2014, 508, 117-128.

39. Douglass, J.G.; Duffy, J.E.; Canuel, E.A. Food web structure in a Chesapeake Bay eelgrass bed as determined through gut content and ${ }^{13} \mathrm{C}$ and ${ }^{15} \mathrm{~N}$ isotope analysis. Estuar. Coast. 2011, 34, 701-711.

40. Chapman, J.W. Gammaridea. In The Light and Smith Manual: Intertidal Invertebrates from Central California to Oregon, 4th ed.; Carlton, J.E., Ed.; University of California Press: Berkely, CA, USA, 2007; pp. 545-618. 
41. Pilgrim, E.M.; Darling, J.A. Genetic diversity in two introduced biofouling amphipods (Ampithoe valida and Jassa marmorata) along the Pacific North American coast: Investigation into molecular identification and cryptic diversity. Divers. Distrib. 2010, 16, 827-839.

42. Sotka, E. (College of Charleston, Charleston, SC, USA); Scheinberg, L. (Romberg Tiburon Center, San Francisco State University, Tiburon, CA, USA); Boyer, K.E. (Romberg Tiburon Center, San Francisco State University, Tiburon, CA, USA). Unpublished data, 2014.

43. Watling, L.; Carlton, J.T. Caprellidae. In The Light and Smith Manual: Intertidal Invertebrates from Central California to Oregon, 4th ed.; Carlton, J.T.; Ed.; University of California Press: Berkeley, CA, USA, 2007; pp. 618-629.

44. Carlton, J.T. Introduced marine and estuaring mollusks of North America: An end-of-the-20th-century perspective. J. Shellfish Res. 1992, 11, 489-505.

45. Carlton, J.T. The Light and Smith Manual: Intertidal Invertebrates from Central California to Oregon, 4th ed.; University of California Press: Berkeley, CA, USA, 2007.

46. Boyer, K.E. Romberg Tiburon Center, San Francisco State University, Tiburon, CA, USA. Unpublished data, 2014.

47. Folin, O.; Ciocalteu, V. Of tyrosine and tryptophan determinations in proteins. J. Biol. Chem. 1927, 73, 627-650.

48. Bolser, R.C.; Hay, M.E.; Lindquist, N.; Fenical, W.; Wilson, D. Chemical defenses of freshwater macrophytes against crayfish herbivory. J. Chem. Ecol. 1998, 24, 1639-1658.

49. Quackenbush, R.C.; Bunn, D.; Lingren, W. HPLC determination of phenolic acids in the water soluble extract of Zostera marina L (eelgrass). Aquat. Bot. 1986; 24, 83-89.

50. Ruxton, G.D. The unequal variance t-test is an underused alternative to Student's t-test and the Mann-Whitney U test. Behav. Ecol. 2006, 17, 688-690.

51. Williams, S.L.; Ruckelshaus, M.A. Effects of nitrogen availablity and herbivory on eelgrass (Zostera marina) and epiphytes. Ecology 1993, 74, 904-918.

52. Hughes, A.R.; Best, R.J.; Stachowicz, J.J. Genotypic diversity and grazer identity interactively influence seagrass and grazer biomass. Mar. Ecol. Progr. 2010, 403, 43-51.

53. Yun, H.Y.; Rohde, S.; Linnane, K.; Wahl, M.; Molis, M. Seaweed-mediated indirect interaction between two species of meso-herbivores. Mar. Ecol. Progr. 2010, 408, 47-53.

54. Buchsbaum, R.; Valiela, I.; Swain, T. The role of phenolic compounds and other plant constituents in feeding by Canada geese in a coastal marsh. Oecologia 1984, 63, 343-349.

55. Harrison, P.G.; Durance, C. Seasonal variation in phenolic content of eelgrass shoots. Aquat. Bot. 1989, 35, 409-413.

56. Vergeer, L.H.T.; Aarts, T.L.; de Groot, J.D. The "wasting disease" and the effect of abiotic factors (light intensity, temperature, salinity) and infection with Labyrinthula zosterae on the phenolic content of Zostera marina shoots. Aquat. Bot. 1995, 52, 35-44.

57. Buchsbaum, R.N.; Short, F.T.; Cheney, D.P. Phenolic-nitrogen interactions in eelgrass, Zostera marina L.: Possible implications for disease resistence. Aquat. Bot. 1990, 37, 291-297.

58. Ceh, J.; Molis, M.; Dzeha, T.M.; Wohl, M. Induction and reduction of anti-herbivore defenses in brown and red macroalgae off the Kenyan Coast. J. Phycol. 2005, 41, 726-731.

59. Taylor, R.B.; Sotka, E.; Hay, M.E. Tissue-specific induction of herbivore resistance: Seaweed response to amphipod grazing. Oecologia 2002, 132, 68-76. 
60. Icely, J.D.; Nott, J.A. Feeding and digestion in Corophium volutator. Mar. Biol. 1985, 89, 183-195.

61. Ort, B.S.; Cohen, C.S.; Boyer, K.E.; Wyllie-Echeverria, S. Population structure and genetic diversity among eelgrass (Zostera marina) beds and depths in San Francisco Bay. J. Hered. 2012, 103, 533-546.

62. Bischoff, A.; Tremulot, S. Differentiation and adaptation in Brassica nigra populations: Interactions with related herbivores. Oecologia 2011, 165, 971-981.

63. Vergeer, L.H.T.; Develi, A. Phenolic acids in healthy and infected leaves of Zostera marina and their growth-limiting properties toward Labyrinthula zosterae. Aquat. Bot. 1997, 58, 65-72.

64. Ramamurthy, M.S.; Maiti, B.; Thomas, P.; Nair, P.M. High-performance liquid chromatography determination of phenolic acids in potato tubers (Solanum tuberosum) during wound healing. J. Agr. Food Chem. 1992, 40, 569-572.

65. Li, J.Y.; Oulee, T.M.; Raba, R.; Last, R.L. Arabidopsis flavanoid mutants are hypersensitive to UV-B radiation. Plant Cell 1993, 5, 171-179.

66. Landry, L.G.; Chapple, C.C.S.; Last, R.L. Arabidopsis mutants lacking phenolic sunscreens exhibit enhanced ultraviolet-B injury and oxidative damage. Plant. Physiol. 1995, 109, 1159-1166.

67. Close, D.C.; McArthur, C. Rethinking the role of many plant phenolics: protection from photodamage not herbivores? Oikos 2002, 99, 166-172.

68. Denno, R.F.; Kaplan I. Plant-mediated interactions in herbivorous insects: mechanisms, symmetry, and challenging the paradigms of competition past. In Ecological Communities: Plant Mediation in Indirect Interaction Webs; Ohgushi, T., Craig, T.P., Price, P.W., Eds.; Cambridge University Press: New York, NY, USA, 2007; pp.19-50.

69. Denno, R.F.; Peterson, M.A.; Gratton, C.; Cheng, J.; Langellotto, G.A.; Huberty, A.F.; Finke, D.L. Feeding-induced changes in plant quality mediate interspecific competition between sap-feeding herbivores. Ecology 2000, 81, 1814-1827.

70. Long, J.D.; Mitchell, J.L.; Sotka, E.E. Local consumers induce resistance differentially between Spartina alterniflora populations in the field. Ecology 2011, 92, 180-188.

71. Molis, M.; Enge, A.; Karsten, U. Grazing impact of, and indirect interactions between mesograzers associated with kelp (Laminaria digitata). J. Phycol. 2010, 46, 76-84.

72. Viejo, R.M.; Arrontes, J. Interactions between mesograzers inhabiting Fucus vesiculosus in Northern Spain. J. Exp. Mar. Biol. Ecol. 1992, 162, 97-111.

(C) 2014 by the authors; licensee MDPI, Basel, Switzerland. This article is an open access article distributed under the terms and conditions of the Creative Commons Attribution license (http://creativecommons.org/licenses/by/4.0/). 